Л. А. Онуфрієвої. Кам'янець-Подільський: Медобори-2006, 2019. C. $15-18$.

2. Nina Atamanchur, Svetlana Yalanska, Valentyna Onipko, Volodymyr Ishchenko Motivation of freshmen of high educational establishments: psychological resource of art practice. SUSTAINABLE development under the conditions of European integration: collective monograph / [editorial board Darko Bele, Lidija Weis, Nevenka Maher]. Part I. Ljubljana: Ljubljana School of Business, 2019. P. 89-102.

DOI https://doi.org/10.30525/978-9934-588-80-8-1.22

\title{
ПОЧУТТЯ ТРИВОГИ В МЕЖАХ ДУХОВНОЇ ПРОБЛЕМАТИКИ
}

\author{
Железнякова Ю. В. \\ кандидат психологічних наук, \\ дочент кафедри психології \\ Запорізький національний університет \\ м. Запоріжжя, Украӥна
}

Метою роботи є теоретичний аналіз наукової думки щодо почуття тривоги у зв'язку з духовним життям людини.

Тривога - поширений і знайомий кожній людині стан. I 3 самого початку історії людства почуття тривоги було пов'язано з духовними i екзистенційними проблемами. У анімістичних культурах люди страждали від неспокою і тривоги в небезпечному світі. Правила та ритуали, які формувалися в той період, були призначені для організації безпеки через заспокоєння божеств, духів предків. А це, в свою чергу, сприяло зниженню почуття тривоги. У більш пізній період філософи $\mathrm{i}$ психологи розглядали тривогу як втрату внутрішньої свободи, яка вважалася ядром людського існування. I нарешті, з кінця 19-го століття, філософи, соціологи і психологи стали пов'язувати тривогу 3 культурними i духовними перетвореннями в контексті ситуацій невизначеності.

Сучасна людина, як на своєму особистому досвіді, так i 3 спостережень за життям оточуючих, може спостерігати, що нічого кардинально не змінилося в переживанні тривоги з часів пантеїзму, що i в наш час феномен тривоги охоплює всі сторони людського життя. I якщо на зорі людства тривога багато в чому була пов'язана 3 реальною небезпекою для життя, то в сучасному світі люди відчувають 
свою тривогу, пов'язану не стільки з зовнішніми причинами, скільки 3 внутрішніми психічними і психологічними процесами. До останніх ми можемо віднести внутрішнє сум'яття, страх відчуження, відкидання, втрату сенсів, неадекватну самооцінку, страх невдач і багато іншого. В контексті цього важливо розуміти, що в принципі, будь-який самостійний психічний стан людини також є формою його духовності. Інтенція тривоги, страху, сумніву, провини і інших онтологічних переживань пов'язана 3 екзистенційними ціннісними орієнтаціями свідомості. Однак дослідження релігійних і духовних проблем при тривозі відстає в порівнянні з дослідженням психічних порушень.

На даний момент існують дослідження, які вказують, що приналежність до будь-якої релігії пов'язана з більш низьким рівнем тривоги; духовність негативно корелює 3 меншою кількістю неспокою і тривоги, але позитивно з почуттям безпеки. Релігійність, особливо духовність, мають позитивний зв'язок з психологічним здоров'ям. Деякі дослідники також продемонстрували, що більш високий рівень духовного благополуччя пов'язаний 3 більш низьким рівнем змінних психологічного дистресу, таких як депресія, безнадія, тривожність, суїцидальна поведінка [5]. Проблема полягає в тому, що в цих дослідженнях не визначений причинно-наслідковий зв'язок.

Також сучасні психологічні та соціальні дослідження рідко розглядають духовні, екзистенційні та культурні аспекти тривоги. Зазвичай тривогу описують і аналізують з точки зору людини, яка сама реалізується, в діяльності, яка весь час ускладняється. Тривога, в такому випадку, виступає побічним, але природним наслідком розвитку і адаптації людини [1].

На більш глибокому рівні зазвичай розглядається патологічна тривога, яка співвідноситься 3 психіатричною практикою систем класифікацій, таких як DSM-IV і MKX. Деякі з цих тривог складно виявити, особливо соціальні тривожні розлади, обсесивно-компульсивні розлади, посттравматичні стресові розлади і прості фобії, так як люди часто приховують симптоми [4].

В рамках клінічної психології ми можемо вказувати тип дисфункції і причини порушення нормального функціонування афективної сфери. Зазвичай їх відносять до тривожних розладів, які часто до норми віднести складно.

В науковій літературі, як правило, виділяють сім типів базового, екзистенціального занепокоєння: занепокоєння, пов'язане $з$ втратою структури (відносин Я-Я, наприклад); занепокоєння, пов'язане 3 фактом свого існування (нездатність жити); тривога, що виражає відсутність безпеки та фізичного захисту; тривога як вираз 
незв'язаності та ізоляції; тривога, пов'язана з сумнівом і неможливості робити вибір; тривога як вираз почуття безглуздості; і тривога (страх) смерті. Останні чотири (ізоляція, втрата свободи, безглуздість, смерть) широко обговорюються в роботах гуманістичних психологів і психотерапевтів і мають досвід роботи в феноменологічних традиціях. Описи перших трьох можна знайти в психопатологічної літературі [3].

Тому важливо розділяти тривогу клінічну і нормальну, так як $\epsilon$ ризик втратити уявлення про повсякденну «побутову» тривогу і то, як духовність, релігійність впливають на щоденні емоційні стани. Кожна 3 існуючих теорій тривоги звертає увагу і на актуальні симптоми, i на фундаментальні структури. Однак істотний недолік всіх цих теорій полягає в тому, що відсутнє ясне розрізнення між екзистенціальною тривогою і патологічною тривогою. Також важливо в питанні вивчення почуття тривоги розуміти, що релігійні, духовні, екзистенційні складності можуть стати самі по собі причиною тривожних станів людини. Так, наприклад, згідно з визначенням П. Тілліха, тривога є людською реакцією на загрозу небуття. Загроза небуття відноситься до релігійної та духовної сфери життя. Р. Нібур стверджув, що будь-яка діяльність людини включає в себе елемент тривоги [2]. Більш того, на його думку попередньою умовою гріха $\epsilon$ тривога. I в цьому він співзвучний 3 3. Фрейдом, який виділяв тривогу, як «вузлову проблему». З. Фрейд вважав, що проблема тривоги відноситься не тільки до розуміння емоційних і поведінкових розладів або до їх терапії. Він стверджував, що вирішення проблеми тривожних станів людини дасть відповіді на всі питання щодо психічного життя людини.

Крім того С. К'єркегор, випереджаючи уявлення К. Хорні та інших вчених про цей феномен, вказував на те, що з одного боку, тривога свідчить про наявність проблеми, яку необхідно вирішити, а з іншого що це $\epsilon$ рушійна сила розвитку, яка дозволяє людині розвивати здатність бути Собою. I тільки таким способом особистість досягає зрілості, що дозволяє нам співвіднести цей феномен 3 духовними, екзистенційна складнощами.

Тому так важливо досліджувати те, як духовність пов'язана 3 іншими психологічними, соціальними і поведінковими проявами тривоги. Більш глобально це може виглядати як аналіз залежності між різними аспектами тривоги, їх екзистенційними i духовними причинами і то, як ми за допомогою тієї ж духовності і релігійності можемо справлятися з повсякденним занепокоєнням. 


\title{
Література:
}

1. Бурняшева Л. А., Газгиреева Л. Х. Духовный кризис ценностных оснований: социально-философский дискурс проблемы / Перспективы науки. 2011. №. 2. С. 52.

2. Нибур Райнхольд / Митрохин Л. Н. / Новая философская энциклопедия : в 4 т. / пред. науч.-ред. совета В. С. Стёпин. - 2-е изд., испр. и доп. Москва. 2010. С. 2816.

3. Baetz, M., Bowen, R., Jones, G., \& Koru-Sengul, T. How spiritual values and worship attendance relate to psychiatric disorders in the Canadian population.The Canadian Journal of Psychiatry. 2006. № 51(10). P. 654-661.

4. Glas G., Poort Z. Anxiety, anxiety disorders, religion and spirituality. Southern medical journal. 2007. T. 100. №. 6. P. 621-625.

5. Hills, J., Paice, J. A., Cameron, J. R., \& Shott, S. Spirituality and distress in palliative care consultation. Journal of palliative medicine. 2005. № 8(4). P. 782-788.

DOI https://doi.org/10.30525/978-9934-588-80-8-1.23

\section{ПОКАЗНИКИ СТАНУ СФОРМОВАНОСТІ СОЦІОКУЛЬТУРНИХ ЦННОСТЕЙ СТУДЕНТІВ ЗВО У СУЧАСНИХ УМОВАХ}

\author{
Заредінова Е. Р. \\ кандидат педагогічних наук, дочент, \\ старший науковий співробітник лабораторії морального, \\ громадянського та міжкультурного виховання \\ Інститут проблем виховання \\ Національної академії педагогічних наук України \\ м. Київ, Украӥна
}

Формування ціннісно-смислової сфери особистості $є$ актуальним напрямом сучасної освіти. Аксіологічна сфера $\epsilon$ регулятором й мотиватором поведінки особистості, а соціокультурні цінності, що відбивають культурні досягнення суспільства, а також притаманну даній культурі ментальність й унікальність - ії суттєвим складником. Отже в соціокультурних цінностях синтезується суспільне, культурне й особистісне. Доцільність й важливість дослідження саме соціокультурних цінностей особистості детермінують глобалізаційні та євроінтеграційні виміри сучасного суспільства. 